\title{
Prevalence of Helicobacter pylori Infection in Adult Patients with Dyspeptic Symptoms in Abdi Waluyo Hospital Jakarta from January 2017 to December 2019
}

\author{
Maureen Irawati*, Felix Aloysius Budimutiar*, Guntur Darmawan,***, \\ Deborah Theresia Budimutiar***, Marcellus Simadibrata**** \\ *Department of Internal Medicine, Abdi Waluyo Hospital, Jakarta \\ **Department of Internal Medicine, Faculty of Medicine, Krida Wacana Christian University, Jakarta \\ ${ }^{* * *}$ Department of Clinical Pathology, Abdi Waluyo Hospital, Jakarta \\ ****Division of Gastroenterology, Department of Internal Medicine, Faculty of Medicine, \\ Universitas Indonesia/Dr. Cipto Mangunkusumo General National Hospital, Jakarta
}

\section{Corresponding author:}

Marcellus Simadibrata. Division of Gastroenterology, Department of Internal Medicine, Dr. Cipto Mangunkusumo General National Hospital. Jl Diponegoro No. 71 Jakarta Indonesia. Phone: +62-21-3153957; facsimile: +62-21-3142454.E-mail:prof.marcellus.s@gmail.com

\begin{abstract}
Background: Helicobacter pylori infection is a global public health problem and may be present in more than half of the world's population. Prevalence in developing country higher compared to developed country. However, in Indonesia prevalence of Helicobacter pylori infection is still low compare to other Asian countries. This study aims to determine the prevalence of Helicobacter pylori infection in Abdi Waluyo Hospital Jakarta from January 2017 to December 2019.

Method: In this descriptive study, a total of 772 adult patients were tested using Urea Breath Test-14C for detection of isotopic carbon produced by Helicobacter pylori ability to broke down urea.

Results: Prevalence of Helicobacter pylori infection in Abdi Waluyo hospital between January 2017 December 2019 was 20.98\% with endoscopic findings as follows: $17.48 \%$ with gastritis, $3.24 \%$ with gastric ulcers , $0.26 \%$ with gastric cancer

Conclusion: Increase prevalence of Helicobacter pylori infection every year in Abdi Waluyo hospital. It is suggested to perfom Urea Breath Test for adult patients with dyspeptic symptoms to screened Helicobacter pylori infection.
\end{abstract}

Keywords: Helicobacter pylori infection, urea breath test, prevalence, gastritis, gastric ulcer, gastric malignancy

\begin{abstract}
ABSTRAK
Latar belakang: Infeksi Helicobacter pylori merupakan masalah kesehatan masyarakat dunia dan mungkin telah ada dalam lebih dari setengah populasi dunia. Prevalensi di negara berkembang lebih tinggi dibandingkan dengan negara maju. Akan tetapi, di Indonesia prevalensi infeksi Helicobacter pylori lebih rendah dibanding dengan negara Asia lainnya. Penelitian ini bertujuan menentukan prevalensi infeksi Helicobacter pylori di Rumah Sakit Abdi Waluyo Jakarta dari Januari 2017 sampai Desember 2019.

Metode: Dalam penelitian potong-lintang ini, total 772 pasien dewasa diuji menggunakan Uji Nafas Urea$14 C$ untuk mendeteksi isotop karbon yang dihasilkan oleh kemampuan Helicobacter pylori dalam mengurai urea.
\end{abstract}


Hasil: Prevalensi infeksi Helicobacter pylori di Rumah Sakit Abdi Waluyo dari Januari 2017-Desember 2019 adalah 20.98\% dengan hasil endoskopi seperti berikut: $17.48 \%$ dengan gastritis, 3.24\% dengan tukak peptic, $0.26 \%$ dengan keganasan lambung.

Simpulan: Kenaikan prevalensi dari infeksi Helicobacter pylori setiap tahunnya di Rumah Sakit Abdi Waluyo. Disarankan untuk melakukan Uji Nafas Urea untuk pasien dengan keluhan dyspepsia untuk skrining infeksi Helicobacter pylori.

Kata kunci: infeksi Helicobacter pylori, urea breath test, prevalensi, gastritis, tukakpeptik, keganasan lambung

\section{INTRODUCTION}

Helicobacter pylori is a gram-negative bacillus that grows in the digestive tract. Some studies have shown that approximately $50 \%$ of the world population is infected with the organism, and the prevalence is higher in developing countries like Indonesia. ${ }^{1}$ There is an association between the gastric colonization of H. pylori and chronic gastritis, peptic ulcer diseases and gastric cancer. ${ }^{2}$ Varied prevalence in different locations in Indonesia maybe because several factors related to host-agent-environment. ${ }^{3}$ There are several risk factors for Helicobacter pylori infection are related to: crowded conditions, no supply of clean water, developing country, living with someone who has a Helicobacter pylori infection. ${ }^{4}$

Helicobacter pylori can survive in acidic environment of the stomach. Helicobacter pylori infection often don't have any symptoms but can lead to gastritis, peptic ulcer, dan gastric malignancy. The most common manifestation of Helicobacter pylori is gastritis. Almost $95 \%$ of the infected patients usually have antral gastritis which predisposes to duodenal ulcers, whereas the less common corpus-predominant gastritis is a risk factor for gastric ulcers. ${ }^{5}$ Patients younger than 55 years old who have new-onset dyspepsia without alarm features (family history of proximal gastrointestinal cancer, gastrointestinal bleeding, odynophagia, progressive dysphagia, unexplained iron-deficiency anemia, unintentional weight loss, persistent vomiting, palpable mass or lymphadenopathy, jaundice) should undergo Helicobacter pylori testing and treatment if the infection is confirmed. ${ }^{6}$

Many invasive and non-invasive methods can be used to diagnose $H$. pylori infection, including endoscopy with biopsy, serology for immunoglobulin titers, stool antigen analysis, and the urea breath test (UBT). Positive UBT indicates an active $H$. pylori infection which require treatment or further confirmation with invasive procedures. ${ }^{7}$ Therefore, this study aims to describe the Prevalence of Helicobacter pylori infection in adult patients with dyspeptic symptoms in Abdi Waluyo Hospital Jakarta from January 2017 to December 2019, where we tried to confirmed the positive UBT result with morphological images of the gaster by gastroscopy.

\section{METHOD}

This study is a descriptional study of 772 adult patients more than 18 years of age admitted and outpatient with dyspeptic symptoms at Abdi Waluyo Hospital from January 2017 to December 2019. All adult patients were tested for Helicobacter pylori infection using UBT-14C. All patients need to stop taking any Helicobacter pylori sensitive medicine such as antibiotics, bismuth and proton pump inhibitor compound one month before the test since the medicine may affect the test results. Patients prepared for the breath test by fasting for at least 3 hours before taking a capsule with warm water. The whole capsule must be swallowed without chewing or broken. After waiting for 15 minutes, patient will be required to blow to the breath card until the indicator turned to the right colour. The card will then plug into the slot of the analyzer to obtain the diagnostic results. The entire process of the breath test will take about 25 minutes. We log and process the datum with Microsoft Excel 2010.

\section{RESULTS}

A total of 772 adult patients were tested with UBT and underwent endoscopic procedure in Abdi Waluyo Hospital. Table 1 shows the gender distribution of patients with positive UBT. Table 2 shows age distribution of patients with positive UBT. Age group 46-60 years shows the most number of patients with UBT positive. In Table 3 and 4 shows prevalence of UBT positive patients dan the endoscopic findings of those patients. Prevalence of Helicobacter pylori infection in Abdi Waluyo hospital between January 2017 - December 2019 was $20.98 \%$ with endoscopic findings as follows: $17.48 \%$ with gastritis, $3.24 \%$ with gastric ulcers , $0.26 \%$ with gastric cancer. 
In 2017 , there were prevalence of $6.45 \%$ Helicobacter pylori infection patients with endoscopic findings as follows: $4.84 \%$ with gastritis, $1.61 \%$ with gastric ulcers, $0 \%$ with gastric cancer. In 2018, there were prevalence of $17.57 \%$ Helicobacter pylori infection patients with endoscopic findings as follows: $12.13 \%$ with gastritis, $5.02 \%$ with gastric ulcers , 0.42 $\%$ with gastric cancer. In 2019, there were prevalence of $36.49 \%$ Helicobacter pylori infection patients with endoscopic findings as follows: $32.98 \%$ with gastritis, $3.16 \%$ with gastric ulcers , $0.35 \%$ with gastric cancer.

Table 1. Gender distribution of patients with positive urea breath test (UBT) in Abdi Waluyo Hospital

\begin{tabular}{llll}
\hline Year & Gender & $\begin{array}{l}\text { Total number } \\
\text { tested }\end{array}$ & $\begin{array}{l}\text { Total number } \\
\text { urea breath test (UBT) } \\
\text { positive/n (\%) }\end{array}$ \\
\hline 2017 & Male & 127 & $10(7.87)$ \\
& Female & 122 & $6(4.92)$ \\
2018 & Male & 131 & $25(19.08)$ \\
& Female & 108 & $7(15.74)$ \\
2019 & Male & 111 & $43(34.13)$ \\
& Female & 137 & $60(34.86)$ \\
\hline
\end{tabular}

Total number tested male from are 369 , with total number of UBT positive is $78(21.1 \%)$. Total number tested female are 367 , with total number of UBT positive is $73(19.8 \%)$

Table 2. Age distribution of patients with positive urea breath test (UBT) in Abdi Waluyo Hospital

\begin{tabular}{llll}
\hline Year & Age (years) & $\begin{array}{l}\text { Number } \\
\text { tested }\end{array}$ & $\begin{array}{l}\text { Total number } \\
\text { urea breath test } \\
\text { (UBT) positive }\end{array}$ \\
\hline 2017 & $16-25$ & 14 & 0 \\
& $26-35$ & 37 & 2 \\
& $36-45$ & 61 & 5 \\
& $46-60$ & 98 & 6 \\
& $>60$ & 38 & 2 \\
\hline 2018 & Total number tested & $\mathbf{2 4 8}$ & 15 \\
& $16-25$ & 15 & 6 \\
& $26-35$ & 29 & 3 \\
& $36-45$ & 63 & 9 \\
& $46-60$ & 81 & 16 \\
& $>60$ & 51 & 11 \\
\hline 2019 & Total number tested & 239 & 60 \\
& $16-25$ & 19 & 5 \\
& $26-35$ & 50 & 23 \\
& $36-45$ & 50 & 24 \\
& $46-60$ & 107 & 39 \\
& $>60$ & 58 & 13 \\
& Total number tested & 284 & 104 \\
\hline
\end{tabular}

Table 3. Prevalence of patients with positive urea breath test (UBT) in Abdi Waluyo Hospital

\begin{tabular}{lll}
\hline Year & Total number tested & $\begin{array}{l}\text { Total number urea breath test } \\
\text { (UBT) positive/ } \mathbf{n}(\%)\end{array}$ \\
\hline 2017 & 248 & $16(6.45)$ \\
2018 & 239 & $42(17.57)$ \\
2019 & 285 & $104(36.49)$ \\
\hline
\end{tabular}

Table 4. Endocopic findings prevalence of patients with positive urea breath test (UBT) in Abdi Waluyo Hospital

\begin{tabular}{llll}
\hline Year & Gastritis & Gastric ulcer & Gastric Ca \\
\hline 2017 & $4.84 \%$ & $1.61 \%$ & $0 \%$ \\
2018 & $12.13 \%$ & $5.02 \%$ & $0.42 \%$ \\
2019 & $32.98 \%$ & $3.16 \%$ & $0.35 \%$ \\
\hline
\end{tabular}

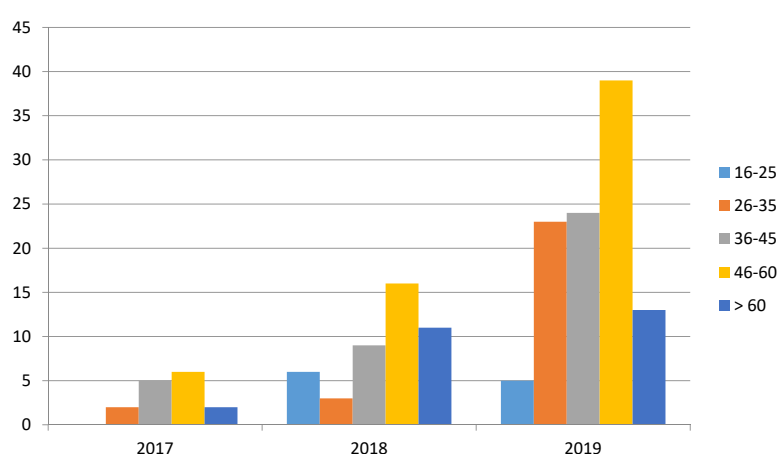

Figure 1. H. pylori positive results by age group. Percentage of urea breath test (UBT) positive individuals across age ranges spanning $16-25,26-35,36-45,46-60$, >60

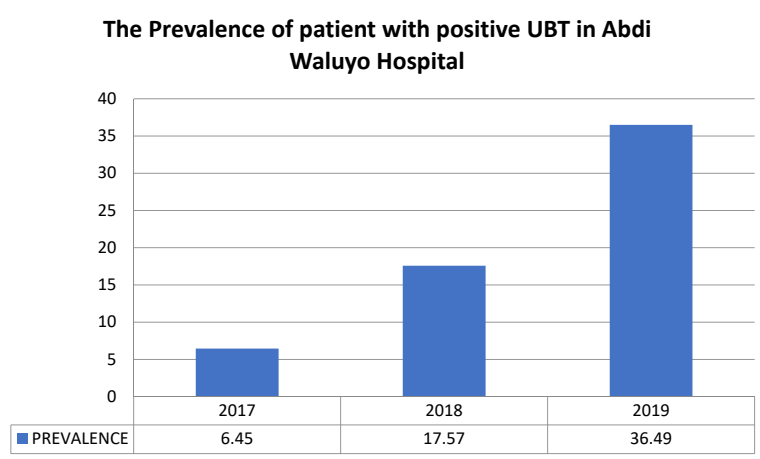

Figure 2. The Prevalence of patient with positive UBT in Abdi Waluyo Hospital, $2017-6,45 \% ; 2018=17,57 \% ; 2019=36,49 \%$.

Endocopic findings prevalence of patients with positive UBT in Abdi Waluyo Hospital

$\square$ Gastritis $\square$ Gastric ulcer $\square$ Gastric Cancer

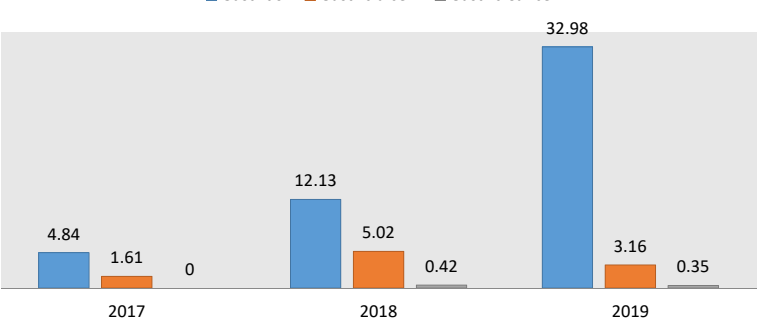

Figure 3. Endocopic findings prevalence of patients with positive urea breath test (UBT) in Abdi Waluyo Hospital

\section{DISCUSSION}

The main finding of our study are that more males with UBT positive than females. Most of H.pylori related disease are associated with male sex. This finding is inline with most of studies In Metaanalysis of large, population based studies, de Martel and Pasonnet analysed the role of gender as a risk factor for $H$. pylori infection. ${ }^{8}$

Otherwise, the study from Moshkowitz et all (2012) give the different result .There are more females UBT positive than the male, The difference between the total positive rate among females and males $(34.8 \%$ vs. $37.2 \%)$ was highly significant $(\mathrm{p}=0.0003) .{ }^{8} \mathrm{Khalid}$ 
et al showed an effect of female hormone based on the ovarian cancer and polycystic ovarian syndrome induced gastric cancer and colleagues, have shown that there are gender differences in the manginitude of the gastric cytokine response to $H$. pylori. ${ }^{9}$ But the higher positive result in male population is still debated, since UBT measures the amount of labeled $\mathrm{CO}_{2}$ exerted through the lungs in exhaled breath. Thus, beyond the presence of $\mathrm{H}$. pylori urease that hydrolyzes the urea into ammonia and labeled $\mathrm{CO} 2$, factors affecting endogenous production of $\mathrm{CO}_{2}$ have an impact on UBT quantitative results. Endogenous production of $\mathrm{CO}_{2}$ depends much on basal metabolic rate, which differs according to sex and body surface area (a function of weight and height). Which it should be higher in man. ${ }^{10}$

Recall that $H$. pylori infection is usually acquired in childhood, with the onset of symptoms and complications usually occurring much later in life. Our data in Figure 1 and Supplementary Table 2 show that the onset of $H$. pylori related disease occurs with significant over-representation of people in the 46-60 age range among those with positive UBT results. ${ }^{11}$

Epidemiological studies in developing countries show that the prevalence of $H$. pylori infection increases with age because of inadequate hygiene, low education level, and low socioeconomic conditions. According to the study from Murat Sadic et all, there were 1,390 cases were $H$. pylori- positive. The rate of UBT positivity was $43 \%$ in the pediatric group, $50 \%$ in the adult group, and $44 \%$ in the geriatric group. The difference was statistically significant between pediatrics and the other age groups $(p=0.043)$. A positive correlation was found between C14- UBT positivity and age $(r=0.76)^{12}$

In our study, the prevalence of patient with $H$. pylori positive are increase every year since 2017 to 2019 . The rate of Gatritis is significantly increase every year and the rate of gastric ulcer and gastric cancer in patient is fluctuating. There are some factor that may cause the result, based on the study from Ari Farial syam from Universitas Indonesia, Jakarta, there were difference of several demographic and environmental factors between ethnic groups; age, religion and the source of drinking water were associated with increased risk of infection. Several ethnics in Indonesia showed the age-related prevalence pattern of $H$. pylori infection in developing countries that $H$. pylori infections occur earlier in life and with high frequency. ${ }^{13}$

In parallel with more effective eradication of $H$. pylori, the prevalence of this infection is changing, and the proportion of ulcers that are not associated with $H$. pylori infection seems to be increasing. One possible explanation for the increase in urease negative gastric ulcers in our study may be due to the increase in the usage of NSAIDs in the general population. It is well known that NSAID-related GI complications are increasing worldwide. ${ }^{14}$

This study has potential limitation . the effect are based on descriptional study only allow make summations about the prevalence of of Helicobacter pylori infection in adult patients with dyspeptic symptoms. There are there fore subjects to biases and confounding that may have influenced our study, as its difficult to monitoring the obedience of stop taking any Helicobacter pylori sensitive medicine such as antibiotics, bismuth and proton pump inhibitor compound one month before the test since the medicine may affect the test results, and the variety of morphological gastroscopy findings which may be unique and different

\section{CONCLUSION}

Dispeptic symptoms may associated with gastritis, gastric ulcer and gastric cancer. But its not a definitive association with infection of Helicobacter pylori. Further study needed more inclusion and exclusion criteria to rule out other possible causes of gastritis to minimize biases.

\section{REFERENCES}

1. Syam AF, Miftahussurur M, Makmun D, Nusi IA, Zain LH, Zulkhairi, et al. Risk factors and prevalence of Helicobacter pylori in five largest islands of Indonesia: a preliminary study 2015;10:e140186.

2. Bauer B, Meyer TF. The human gastric pathogen Helicobacter pylori and its association with gastric cancer and ulcer disease. Ulcers J 2011;20:2001-23.

3. Perkumpulan Gastroenterologi Indonesia (PGI) dan Kelompok Studi Helicobacter pylori Indonesia (KSHPI). Konsensus nasional penatalaksanaan dispepsia dan infeksi Helicobacter pylori. Simadibrata M, Makmun D, Abdullah M, Syam AF, Fauzi A, Renaldi K, Maulahela H, Utari AP, eds. Jakarta: PGI KSHPI 2014.

4. Goh KL, Chan WK, Shiota S, Yamaoka Y. Epidemiology of Helicobacter pylori Infection and Public Health Implications. Helicobacter 2011;16:1-9.

5. Watari J, Chen N, Amenta PS, Fukui H, Oshima T, Tomita T, et al. Helicobacter pylori associated chronic gastritis, clinical syndromes, precancerous lesions, and pathogenesis of gastric cancer development. World J Gastroenterol 2014;20:5461-73.

6. Zullo A, Hassan C, Francesco VD, Repici A, Manta R, Tomao S. Helicobacter pylori and functional dyspepsia: An unsolved issue? Helicobacter pylori and Functional Dyspepsia: An Unsolved Issue? World J Gastroenterol 2014;20:8957-63. 
7. Filomena A, Guenther A, Planatscher H, Topin F, She J, Formichella L, et al. Performance of a multiplex serological Helicobacter pylori assay on a novel microfluidic assay platform. Proteomes 2017;5:E24.

8. Moshkowitz M, Horowitz N, Or AB, Halpern Z, Santo E. Gender-associated differences in urea breath test for Helicobacter pylori infection referrals and results among dyspeptic patients. World J Gastrointest Pathophysiol 2012;3:80-4.

9. Alfarouk KO, Bashir AH, Aljarbou AN, Ramadan AM, Muddathir AK, AlHoufie ST, et al. The possible role of Helicobacter pylori in gastric cancer and its management. Front Oncol 2019;9:75.

10. Eisdorfer I, Shalev V, Goren S, Chodick G, Muhsen K. Sex differences in urea breath test results for the diagnosis of Helicobacter pylori infection: a large cross-sectional study. Biol Sex Differ 2018;9:1.

11. Wise MJ, Lamichhane B, Webberley KM. A longitudinal, population-level, big-data study of Helicobacter pylori-related disease across Western Australia. J Clin Med 2019;8:1821.

12. Sadic M, Aydinbelge FN, Koca G, Demirel K, Akbulut A, Kalayci S, et al. Investigation of Helicobacter pylori infection prevalence using C14-urea breath test and its relationship with socioeconomic, family, and environmental factors. Jundishapur J Microbiol 2019;12:1-2.

13. Syam AF, Miftahussurur M, Makmun D, Nusi IA, Zain LH, Zulkhairi, et al. Risk factors and prevalence of Helicobacter pylori in five largest islands of Indonesia: a preliminary study. PLOS ONE 2015;10:2-11.

14. Serin A, Tankurt E, Şarkış C, Simsek I. The prevalence of Helicobacter pylori infection in patients with gastric and duodenal ulcers - a 10-year, single-centre experience. Gastroenterology Review 2015;3:160-3. 